\title{
ANALYSIS OF DIGITALIZATION REFERRED TO IN STRATEGIC POLICY DOCUMENTS IN THE LIFELONG EDUCATION CONTEXT
}

\author{
Modrite Pelse ${ }^{1}$,Dr.oec / professor; Maira Lescevica ${ }^{2}$,Dr.oec / professor \\ ${ }^{1}$ Latvia University of Life Sciences and Technologies; ${ }^{2}$ Vidzeme University of Applied Sciences
}

\begin{abstract}
Previous research studies on digitalization as an important driver of development has been largely discussed in the context of entrepreneurship, determining its effects on economic growth. Over the past decade, the role of digitalization in public administration - in providing quality and user-friendly services - has been stressed, with less emphasis being placed on its importance in strategic planning. The driving force of change is digital transformation, which requires digital skills and knowledge. The digital literacy of European Union residents has improved, yet in seven EU Member States it was rated as low or very low. Lifelong education helps to deal with this problem, and it has become a necessity for the entire society. The aim of the present research is to determine the role of digitalization in strategic policy documents in the context of lifelong education. The paper analysed the National Development Plan of Latvia 2021-2027 (final version), the Digital Agenda 2020 for Estonia and the Progress Strategy "Lithuania 2030". The mentioned strategic documents have set a number of goals and objectives directly relating to the implementation of digitalization in order to facilitate the work of society, enterprises and public administration. The policy documents refer to digitalization in lifelong education as mostly a communication and information tool requiring adequate digital skills to be provided by educational institutions. The research employed the monographic, content analysis and descriptive methods. The strategic policy documents of Latvia have been compared with the corresponding documents of the other Baltic States, as the historical and economic development of the countries has followed a relatively similar scenario, and all the Baltic States are EU Member States.
\end{abstract}

Key words: digitalization, lifelong education, strategic policy documents.

JEL code: I28

\section{Introduction}

Research studies stress the fact that digitalization results in radical changes in the economic patterns of regions and even countries. Competition grows among industries in the domestic market, thereby improving the competitiveness of certain industries in some countries. Consequently, it contributes to national economic growth (Tarasov I., 2018).

Research on digitalization mainly focuses on the digitalization of processes and industries, yet less attention is paid to its role in public institution performance, public policy making and territorial development. Fundamental research studies on change processes in public institutions, which could be the result of applying digital transformation approaches, mostly use the terms related to digitalization, such as e-government, digital government or transformative government. Digitalization involves new knowledge and skills, which, in turn, are acquired through education.

Education should be accessible throughout life, as it is part of our daily lives, an informed choice and a necessity. The overall goal of education policy is a high-quality and inclusive education for personal development, human wellbeing and sustainable national growth as prescribed by the Education Development Guidelines for 2014-2020 (Par izglitibas attistibas ..., 2014).

The research aim is to determine the role of digitalization in strategic policy documents in the context of lifelong education. To achieve the aim, the following specific research tasks have been set: 1 ) to theoretically discuss the importance of digitalization and lifelong education and to outline the interrelationships; 2 ) to perform an assessment of the digital skills of individuals; 3 ) to analyse

\footnotetext{
1 Modrite Pelse; e-mail:modrite.pelse@llu.Iv

2 Maira Lescevica; e-mail: maira.lescevica@va.Iv
} 
the new National Development Plan of Latvia and compare it with the corresponding policy documents of the other Baltic States in the context of digitalization and lifelong education.

Educating the public throughout life has been on the agenda of the main institutions of the EU for several years. Strategic national-level policy documents best project the expected progress in digitalization deployment over the next 7 to 10 years.

The paper analysed the National Development Plan of Latvia 2021-2027 (final version), the Digital Agenda 2020 for Estonia and the Progress Strategy "Lithuania 2030". The research employed the monographic, content analysis and descriptive methods and compared the strategic policy documents of Latvia with the corresponding documents of the other Baltic States, as the historical and economic development of the countries has followed a relatively similar scenario, and all the Baltic States are EU Member States.

\section{Research results and discussion}

\section{Theoretical discussion on lifelong education and digitalization}

The driving force of change is social, industrial or technological advancement (Matt, O. et.al., 2020). The mechanization, electrification and computerization observed in the first decade of the $21^{\text {st }}$ century was followed by "digital transformation" that emerged as the Fourth Industrial Revolution or Industry 4.0 (Berghaus S., 2018). The new technologies driving the Fourth Industrial Revolution build on the knowledge and systems of previous technological revolutions, and particularly on digital possibilities. Digital technologies affect education, training and learning by creating more flexible learning environments tailored to the needs of a highly mobile society (Par pamatkompetencem muzizglitiba, 2018). The Fourth Industrial Revolution is characterized by the following technological fields and features: autonomous robots and robotics; neurotechnology; biotechnology; simulation; horizontal and vertical system integration; the Internet of Things - IOT; cyber security; cloud computing; production of software updates; virtual and augmented reality; autonomous vehicles; 3D printing or spatial printing, big data and related analytics, and ideas and possibilities we do not yet know (Schwab K., 2017). Digital competence, however, involves confident, critical and responsible use of digital technologies and use of these technologies for learning and work purposes as well as for participation in social life. It covers fields such as information and data literacy, communication and cooperation, media literacy, digital content creation (including programming), security (including cybersecurity), intellectual property matters, problem solving and critical thinking.

In a 2018 recommendation on key competences for lifelong learning, the Council of Europe defined digital competence as one of the eight key competences, along with literacy, multilingual, mathematical and technological competences in science, technology and engineering (Par pamatkompetencem muzizglitiba, 2018). Today, target-oriented and meaningful training of human capital's digital skills is important for any country regardless of its national economy specialization (Grinberga-Zalite G., Hernik J., 2019).

Even though it might seem that digital changes occur only in the private sector, government intervention is insignificant (Dosi, G., 2013), and new technological inventions become a means of managing time and space to create an advanced infrastructure and shape a sustainable economic era (Rose G., 2016). Change is the process of replacing a current situation with another, most often unknown, new situation. The goal of national strategic planning is to orientate public administration towards more efficient use of financial, material and human resources by setting specific objectives and targets. The potential for change and the result it could bring have to be seen, and a plan for 
how to achieve the goal has to be drawn up. Action has to be taken, and this change should not be abandoned if facing some difficulty. Change success is teamwork, where everyone is responsible for making a difference. Measuring the degree of readiness for change is a way of understanding the potential, depending on the social and psychological costs incurred (Burke W., 2011). The more organizations are involved in helping to plan and implement changes, the more they support rather than resist the changes. Unfortunately, resistance is understandable - it is a fear of changes or new challenges -, and new skills have to be acquired (Armstrong P., 2017). Changes are often driven by the dissatisfaction of leaders with one or more aspects of the current state (Damodaran L., Olphert W., 2006), yet today the main driver of changes is the use of technological possibilities (Armstrong P., 2017) and a focus on the overall system rather than the technology itself (Schwab K., 2017).

The public, businesses and politicians experience technological change in their environments, lives and work and also expect public administration institutions to adapt accordingly and provide similar technological potential in the delivery of public services. It follows that digitalization in public administration is mainly driven by external rather than internal requirements arising from changes in environmental technologies and demands from private sector organizations and society at large to change the public administration. Digitalization changes the relationship between public administration institutions and the public as users of digital public services, as well as the relationships within organizations themselves (Mergel I., Edelmann N., 2019).

The term e-government is mostly used with regard to the provision of public sector services. The focus is placed not on creating new business models but rather on efforts to make service delivery more efficient and accessible to the public, with a shift from offline to online. The key goal of egovernment is to increase the efficiency of service delivery, while research on digitalization involves analyses of the internal and external environments (Mergel I., Edelmann N., 2019), which goes beyond the delivery of a service. The external environment of digitalization relates to the ability of public institutions to develop an effective regulatory framework and supportive financial assistance policies, while technology and knowledge are the key factor of the internal environment affecting competitiveness (Binde J., 2019).

Knowledge gives us opportunities and helps to shape the future; it is a force that enhances our competitiveness. Knowledge needs to be further built up, and lifelong education has become a necessity for all individuals. We need to build up skills and competences throughout life, not only for our personal growth and our ability to actively cooperate with the community we live in but also to succeed in a constantly changing world (Figel J., s.a.). Lifelong education is a learning process throughout life, which is prompted by the changing needs to acquire knowledge, skills and experience in order to professionally develop or retrain in line with interests, needs and labour market requirements (Kas ir muzizglitiba, s.a.). It should be noted that in Latvia, those who are now forty years old or older have not acquired digital skills at school; they have acquired the skills only owing to lifelong education or autonomous learning.

\section{Digital skills of the population}

At the beginning of 2020, nearly 60 percent of the world's population were online. Of the 7.75 billion people, over 4.5 billion used the Internet, while the number of social media users surpassed the 3.8 billion level. In 2015, some 20 billion devices worldwide were connected to the Internet, while 2.8 billion people worldwide used the Internet (Kemp, 2020); by 2030, this number 
could reach half a trillion. New payment methods (mobile or contactless), the Internet of Things, smart homes (e.g. automated lighting), smart mobility (automated traffic management based on air quality), e-health (e.g. digital patient files) (Pfaffinger, K.F. et.al., 2020) - it is a modern reality that demands new digital skills for its creators and users.

The figure below shows the digital skills of the population in EU Member States - slightly more than half of the EU population, on average, had good or very good digital skills and $40 \%$ had poor or very poor digital skills.

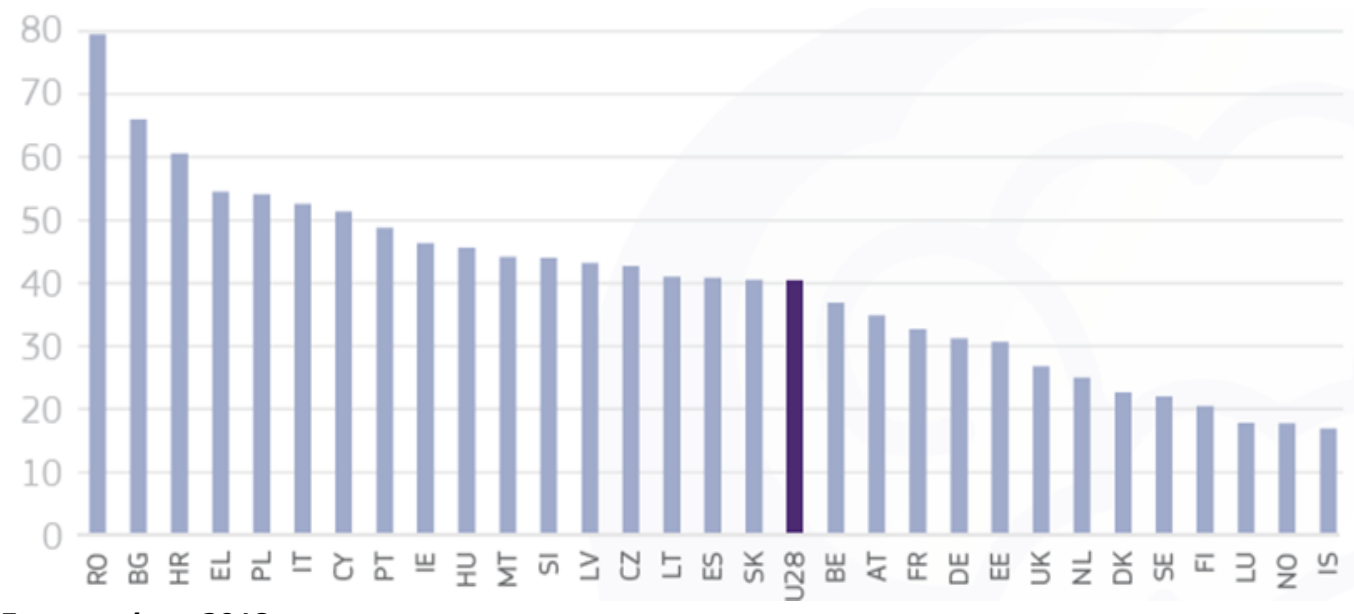

Source: Eurostat data, 2018.

Fig. 1. Percentage of the population with no or poor digital skills in 2018

In several EU Member States - Romania, Bulgaria, Croatia, Spain, Poland, Italy and Cyprus -, the digital literacy of more than $50 \%$ of the population was poor. However, as noted by a group of scientists from LLU, during the last five years, all digital performance indicators in the European Union indicated a positive trend. However, despite the EU Member States' good will to jointly build a digital single market, the digitalization performance gap between the wealthier Member States and less wealthy ones still remained large. Overall, the research results revealed that North European Member States - Finland, Sweden, Denmark, Estonia and Ireland and the Netherlands - reached the highest digital performance results in 2018 (Grinberga-Zalite G. et al., 2019).

Fast digitalization growth is also observed in Germany, whose government has introduced a strategic development plan Industry 4.0 for the manufacturing industry since 2011 . The plan has drawn a lot of attention from both investors and economists. This topic and future challenges were also discussed at LLU Academic Conference 2019 held by Latvia University of Life Sciences and Technologies (LLU). According to professors B.Rivza and P.Rivza, Industry 4.0 best indicates technology convergence and the disappearance of boundaries between physical and digital (Rivza B., Rivza P., 2019). The Smart Specialization Strategy of Latvia also refers to information and communication technologies as a priority area for national development (Pelse M., Lescevica M., 2017).

According to Central Statistical Bureau (CSB) data, the digital skills of the population of Latvia are considered to be mediocre, requiring building up additional skills and knowledge. Analysing the involvement of the population in lifelong education and identifying the reasons that prevented them from doing it, $48.4 \%$ of the respondents said it was too expensive, while $42.2 \%$ said they had no access to computers and/or the Internet to use distance learning programmes (CSB, 2018).

There are quite few systematic empirical research studies on how public administration bodies deal with digital transformation in their daily practice, how they approach digital transformation 
projects and what the expected results have been achieved (Mergel I. et al., 2019). What effects will this have on territorial development, and is digitalization and lifelong education an important component of strategic documents?

\section{Review of digitalization in strategic and policy documents}

Next, the present research analyses the development plans and strategies of the Baltic States that refer to digitalization with regard to the population, education and skills.

\section{Estonia}

The only policy document available in Estonia is the Digital Agenda 2020 for Estonia.

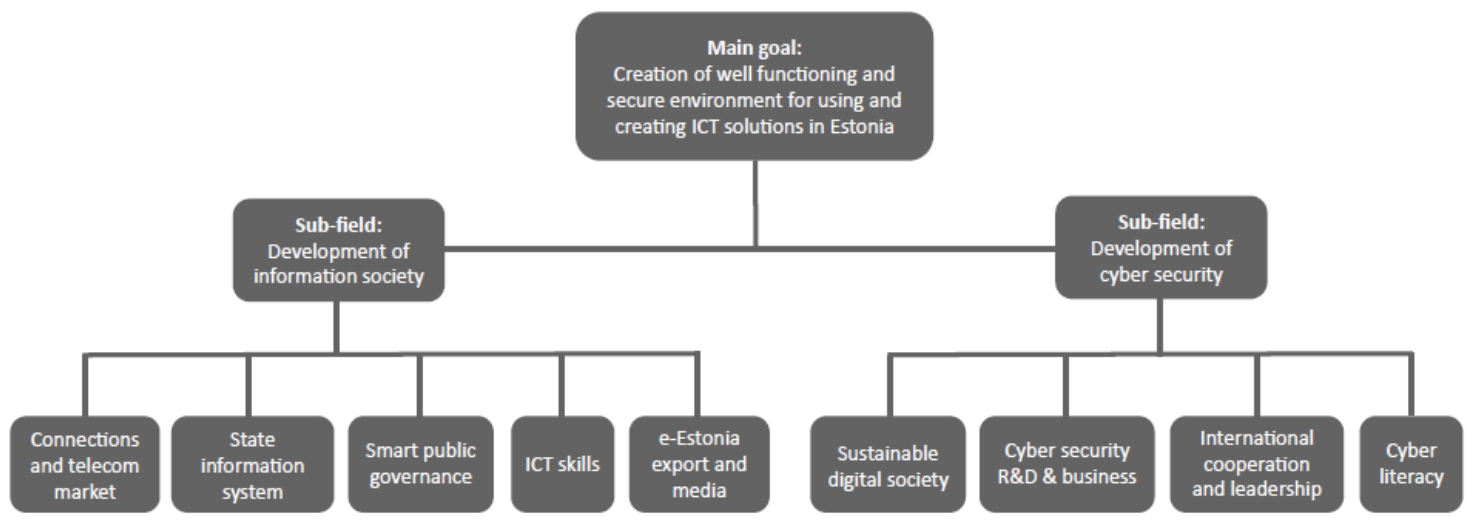

Source: Digital Agenda 2020 for Estonia, 2018.

Fig. 2. General objective, sub-fields and sub-objectives of the Digital Agenda 2020 for Estonia

The goal set what can be find in the only planning document is as follows: "Estonia is a sustainable digital society with strong technological resilience and readiness for coping with a crisis" (Digital Agenda 2020 for Estonia, 2018).

Although the document has other aspects, the primary task is to ensure the resilience of vital functions to cyber threats. Continued in the sub-objective mainly focuses, on resolving the current problems that have the greatest impact, and on ensuring flexible readiness for coping with future threats and risks. The main approach is to possess a state-wide strategic scope, interoperability, a well-functioning community and inclusive planning and development.

\section{Latvia}

One of the priorities of the National Development Plan of Latvia for 2021-2027 is "Knowledge and skills for personality and national growth", aiming to achieve a "knowledgeable, inclusive and creative society in an efficient, innovative and productive economy". It allows concluding that in the global economy, the role of knowledge, entrepreneurial ability, creativity, digital skills and technological competences has become critical, and a lack of them poses a risk of backwardness.

Under the same priority, the activity "High-quality, accessible and inclusive education", the objective of which is provide high-quality education for every resident of the country to acquire knowledge and skills for business and life, also aims to achieve the sub-objective of providing highquality education and effective management of the education system through high-quality implementation of new curricula and learning approaches in general education and dissemination of good practices in teaching, placing a special emphasis on business education and digital skills, education for sustainable development and the development of future skills (creativity, flexibility, adaptability) as well as STEM/STEAM skills (including in interest-related education), improvements in the learning environment, including through digital solutions, personalized learning and talent 
development initiatives and high-quality and comprehensive activities of interest-related education (including in the school environment), effective career education as well as on strengthening school cooperation with parents and other relevant cooperation partners.

For higher education institutions (HEIs), the following objective has been set: "Implementing modern and efficient governance of higher education institutions through involving business organizations in strategic decision-making, contributing to specialization and excellence, digitalizing learning, introducing a quality monitoring system for students, developing and enhancing studentfocused education skills for university teaching personnel, especially in the STEM/STEAM fields, as well as through raising the salaries of teaching personnel and increasing the proportion of highlyqualified foreign teaching personnel.

In addition, the objective of ensuring a comprehensive higher education quality assessment process to assure the quality of higher education and contribute to an internal quality culture of universities, including reviewing the opportunity of introducing cyclic accreditation of universities in 2024, optimizing the number of high-quality study programmes, eliminating the fragmentation and duplication of study programmes, allowing for a flexible simulation of the supply of student-focused education services for acquiring a qualification and retraining, establishing doctoral studies meeting international standards, introducing a tenure system for academic personnel, contributing to introducing new technologies as well as building up digital skills and STEM/STEAM competences, with a special focus on digitalizing the learning process, has been set for academic personnel.

A sub-activity of the above-mentioned activity - "Education for economic growth" - refers to a finding pertaining to lifelong education in particular that "nowadays, digital skills play an important role in everyday life, in the labour market and in entrepreneurship; therefore, building up the skills is necessary regardless of age and has to be introduced and reinforced at all levels and in all forms of education, as well as educational institutions and employers need to be educated on and engaged in it through setting a specific objective of developing digital and new technological skills by designing specific programmes to improve digital skills and promote corporate participation in funding the programmes.

A sub-activity "Adult education" includes a particular objective in the field of lifelong education implementation of adult education for acquisition of skills necessary for economic development, incl. in higher education (development of a flexible supply of education services, including modular education, e-learning and work-based learning, lifelong learning competences; personal profiling; recognition of competences acquired outside formal education).

The indicative budget for implementing the measures of the activity is set at EUR 812.03 million (final version of the NDP 2021-2027).

\section{Lithuania}

The Progress Strategy "Lithuania 2030" reflects a national vision and priorities for development as well as guidelines for their implementation by 2030. This is like a roadmap to be followed for governing in decision making and in drawing up national plans and/ or programmes.

The implementation of the elaborated vision will be based on progress-relevant values such as:

"Openness to a different view, to positive initiatives, to a dialogue, cooperation and innovations;

Creativity in generation and implementation of new ideas, treating challenges as new possibilities of building success; 
Responsibility for actions taken, morality, active concern not only about themselves but also about the environment, community and the country at large" (Lithuania 2030, 2016).

Source: "Lithuania 2030", 2016.

Fig. 3. Concept of the progress strategy "Lithuania 2030"

This strategy envisages gradual changes at national level on areas like smart society, smart economy and smart governance.

The objective of achieving a Smart society involves achieving a "learning society: modern and dynamic, ready for future challenges and able to perform in an ever-changing world" (Lithuania 2030, 2016). This means that the society is open to global changes, the people are well educated, deeply interested in science and innovations, familiar with the latest advances in technologies, good at foreign languages, and eager to pursue lifelong-learning.

One of the key initiatives for achieving a learning society is "To promote Lithuania's development domestically and internationally, focussing on digitalization of the cultural heritage and contemporary cultural content" (Lithuania 2030, 2016).

There is also available a specialized home page www.digitalgov.com, with news and documents from all around the World about digitalization policy, development and performance.

\section{Conclusions, proposals, recommendations}

1) Digital transformation forms the basis for the fourth industrial revolution. It is an important component not only for entrepreneurship development, public administration and society at large, but it is also referred to in strategic policy documents as an important future need, emphasizing the importance of lifelong learning.

2) Digital competence involves confident, critical and responsible use of digital technologies as well as covers fields such as information and data literacy, communication and cooperation, media literacy, digital content creation, security, intellectual property matters, problem solving and critical thinking. This requires advanced digital skills and knowledge, which are gradually built up by the residents of the European Union. However, on average, $40 \%$ of the EU residents had poor or very poor digital skills; among the Baltic States, a better situation was reported in Estonia, where the skills of only $30 \%$ residents could be rated as insufficient.

3) Residents, businesses and politicians experience technological change in their lives and work, expecting public administration institutions to adapt and provide similar technological potential in 
the delivery of public services. Most of the goals and objectives set in the strategic policy documents analysed referred to facilitating particularly the implementation of digitalization in society, enterprises and public administration.

4) The policy document of Estonia, although it has reached the end of its programming period, is nevertheless significantly different from those of the other Baltic States. The policy document of Estonia refers only to the introduction of digitalization, whereas the strategic development plans of Latvia and Lithuania refer to the entire economy, the environment and society in relation to digitalization.

5) Digitalization in lifelong education is mainly referred to as a communication and information tool. The policy document of Latvia focuses mostly on digital skills, and the secondary and higher education systems as well as lifelong education providers have to be involved in building up the skills. The policy documents of Lithuania and Estonia focus particularly on public involvement as well as on making life easier through digital solutions and positioning the society as a smart society.

\section{ACKNOWLEDGEMENTS}

The paper was supported by the NATIONAL RESEARCH PROGRAMME "LATVIAN HERITAGE AND FUTURE CHALLENGES FOR THE SUSTAINABILITY OF THE STATE", project "CHALLENGES FOR THE LATVIAN STATE AND SOCIETY AND THE SOLUTIONS IN INTERNATIONAL CONTEXT (INTERFRAME-LV)".

\section{Bibliography}

1. Armstrong, P. (2017). Disruptive Technologies: Understand, Evaluate, Respond. London: Kogan Page; 1 edition, p. 216.

2. Berghaus, S. (2018) The Fuzzy Front End of Digital Transformation: Activities and Approaches for Initiating Organizational Change Strategies. Retrieved: https://www1.unisg.ch/www/edis.nsf/SysLkpByIdentifier/4704/\$FILE/dis4704.pdf Access: 01.03.2020.

3. Binde, J. (2019). Produktivitates un digitalizacijas attistibas tendencies Latvija (Productivity and Digitalization Trends in Latvia). pp. 147-158. Retrieved: https://www.apgads.lu.Iv/fileadmin/user_upload/lu_portal/apgads/PDF/Monografijas/Produktivitates_celsan a/Produktivitate_4_Binde.pdf.

4. Burke, W.W. (2011). Organization Change: Theory and Practice. SAGE Publications, Inc. Third edition 2011, p. 384.

5. Damodaran, L., Olphert, W. (2006). Informing Digital Futures. Strategies for Citizen Engagement. Springer 2006, p. 226.

6. Digital Agenda 2020 for Estonia (2019). Retrieved: https://www.mkm.ee/sites/default/files/digital_agenda_2020_web_eng_04.06.19.pdf. Access: 25.03.2020.

7. Dosi, G., Galambos, L., (2013) The Third Industrial Revolution in Global Business. Cambridge University Press, 2013, p. 358

8. Figel, J. (2006). Education for Everyone.Worlwide. Lifelong. Journal AED - Adult Education and Development. Retrieved: https://www.dvv-international.de/en/adult-education-and-development/editions/aed$672006 / d v v$-12th-german-adult-education-conference/lifelong-learning-adult-education-and-achieving-thelisbon-goals/ Access: 09.03.2020.

9. Grinberga-Zalite, G., Hernik, J. (2019). Digital Performance Indicators in the EU. In: Research for Rural Development 2019: annual 25th International scientific conference proceedings, Jelgava, Latvia, 15-17 May 2019 / Latvia University of Life Sciences and Technologies. Jelgava. Vol.2, pp.183-188.

10. Grinberga-Zalite, G., Rivza, B., Zvirbule, A., Tihankova, T. (2019). Promoting Digital Skills in Higher Education to Strengthen the Competitiveness of the EU Human Capital. 19th International multidisciplinary scientific GeoConference SGEM 2019: conference proceedings, Albena, Bulgaria / Bulgarian Academy of Sciences Sofia. Vol. 19, pp. 259-266.

11. Kas ir muzizglitiba (What is Lifelong Education) (s.a.). Retrieved: http://www.muzizglitiba.Iv/pieaugusoizglitiba/15. Access: 10.02.2020.

12. Kemp, S. (2020) Digital 2020: Global Digital Overview. Digital trends 2020: Every single stat you need to know about the internet. Retrieved: https://thenextweb.com/growth-quarters/2020/01/30/digital-trends2020-every-single-stat-you-need-to-know-about-the-internet/ Access: 16.03.2020. 
13. Lithuania's Progress Strategy "Lithuania 2030" (2016). Retrieved: https://www.lietuva2030.It/en/about Access: 25.03.2020.

14. Matt, T., Orzes, G., Rauch, E., Dallasegaa, P. (2020) Urban Production - A Socially Sustainable Factory Concept to Overcome Shortcomings of Qualified Workers in Smart SMEs. Computers \& Industrial Engineering, Volume 139.

15. Mergel, I., Edelmann, N., Haug, N. (2019). Defining Digital Transformation: Results from Expert Interviews. Government Information Quarterly June 2019., pp. 1-16.

16. National Development Plan of Latvia 2021-2027 (2020). Final version. Retrieved: https://www.pkc.gov.Iv/sites/default/files/inline-files/NAP2027galaredakcija.pdf. Access: 26.03.2020.

17. Par Izglitibas attistibas pamatnostadnu 2014.-2020.gadam apstiprinasana. Saeimas pazinojums (Approval of the Education Development Guidelines for 2014-2020. Saeima announcement) (2014). Retrieved: https://likumi.Iv/doc.php?id=266406. Access: 21.10.2019.

18. Par pamatkompetencem muzizglitiba (Basic Competences in Lifelong Education) (2018). EU Council Recommendations. Retrieved: https://eur-lex.europa.eu/legalcontent/LV/TXT/PDF/?uri=CELEX:32018H0604(01)\&from=EN. Access: 20.03.2020.

19. Pelse, M., Lescevica, M. (2016). Smart Specialisation Assessment in Latvia. Economics Science for Rural Development: Proceedings of the International Scientific Conference, Nr. 42. Jelgava: LLU, pp. 126-131.

20.Pfaffinger, K.F., Reif, J.A.M., Spieß, E., Berger, R. (2020) Anxiety in a Digitalised Work Environment. Retrieved: https://ezproxy.llu.lv:2134/content/pdf/10.1007/s11612-020-00502-4.pdf Access: 25.01.2020.

21. Rivza, B., Rivza, P. (2019). 4.industriala revolucija: digitala ekonomika un LLU studiju procesa izaicinajumi (4th Industrial Revolution: the Digital Economy and Challenges for the Learning Process at LLU). LLU Academic Conference. 17 p. Retrieved: https://www.Ilu.Iv/sites/default/files/2019-01/AK_2019_B_P_Rivza.pdf. Access: 15.03.2020.

22. Rose, G. (2016). The Fourth Industrial Revolution: A Davos Reader. Council on Foreign Relations. Foreign Affairs. Special Collection. P. 234.

23. Schwab, K. (2017) The Fourth Industrial Revolution. Kindle Edition 2017; p. 192.

24.Тарасов, И. (2018). Индустрия 4.0: понятие, концепции, тенденции развития Стратегии бизнеса. (Russian) No. 6. (Industry 4.0: the Concept, Conceptions, Development Trends. Business Strategy), pp. 5764. 